\title{
Pengaruh Konten Instagram @interstudiofficial dan Opini Mahasiswa terhadap Citra Perguruan Tinggi InterStudi
}

\author{
Isfa Kaharmudzakir ${ }^{1^{*}}$, Mohamad Ichlas El Qudsi ${ }^{2}$ \\ ${ }^{1}$ Sekolah Tinggi Ilmu Komunikasi InterStudi \\ ${ }^{2}$ Pascasarjana Sekolah Tinggi Ilmu Komunikasi InterStudi \\ *Email:khrmudzakir@gmail.com
}

\begin{abstract}
Abstrak
Ketertarikan pengguna Instagram untuk mengetahui informasi dari suatu akun Instagram pihak lain adalah konten yang unik dan menarik yang terdapat didalamnya. Ketika konten dinilai bermanfaat, maka followers akan memberikan komentar dan opini yang positif. Penelitian ini bertujuan untuk mengetahui sejauh mana konten Instagram yang diunggah akun @interstudiofficial dan opini mahasiswa mempengaruhi citra perguruan tinggi InterStudi. Metode riset ini dengan pendekatan kuantitatif eksplanatif, yang dilakukan pada 97 responden yang merupakan followers akun Instagram@interstudiofficial. Penelitian ini ingin menjelaskan hubungan antara tiga variabel. Data dianalisis menggunakan regresi linier berganda. Hasil penelitian menunjukan konten Instagram dan opini mahasiswa berpengaruh terhadap citra perguruan tinggi InterStudi. Temuan tersebut menjelaskan bahwa kontern Instagram yang diunggah oleh akun @interstudiofficial harus bernilai positif sehingga followers akan memberikan komentar dan opini yang akhirnya berpengaruh baik pada citra InterStudi.
\end{abstract}

Kata Kunci: citra, instagram, konten, media sosial, opini mahasiswa

\begin{abstract}
The interest of Instagram users to find out information from another party's Instagram account is the unique and interesting content contained in it. When content is considered useful, followers will provide positive comments and opinions. This study aims to determine the extent to which Instagram content uploaded to the @interstudiofficial account and student opinions affect the image of InterStudi colleges. This research method uses an explanatory quantitative approach, which was carried out on 97 respondents who are followers of the @interstudiofficial Instagram account. This study wants to explain the relationship between the three variables. Data were analyzed using multiple linear regression. The results show that Instagram content and student opinions have an effect on the image of the InterStudi college. These findings explain that the Instagram account uploaded by the @interstudiofficial account must have a positive value so that followers will provide comments and opinions which ultimately have a good effect on InterStudi's image.
\end{abstract}

Keywords: content, instagram, image, social media, student opinion

\section{PENDAHULUAN}

Media sosial merupakan satu hasil perkembangan program komputer berbasis internet yang dapat berinteraksi secara langsung oleh para penggunanya (Zarrella, 2012). Menurut data survei dari situs datareportal.com hingga Januari 2021, dari jumlah penduduk Indonesia sebanyak 275 juta orang, 73,7 \% atau sebanyak 202,6 juta adalah pengguna internet. Masyarakat Indonesia menggunakan internet diantaranya adalah untuk menonton video lewat situs Youtube 93,8 \%, aplikasi pesan Whatsapp 87,7 \%, dan media sosial Instagram $86,6 \%$ (Datareportal.com, 2021). 


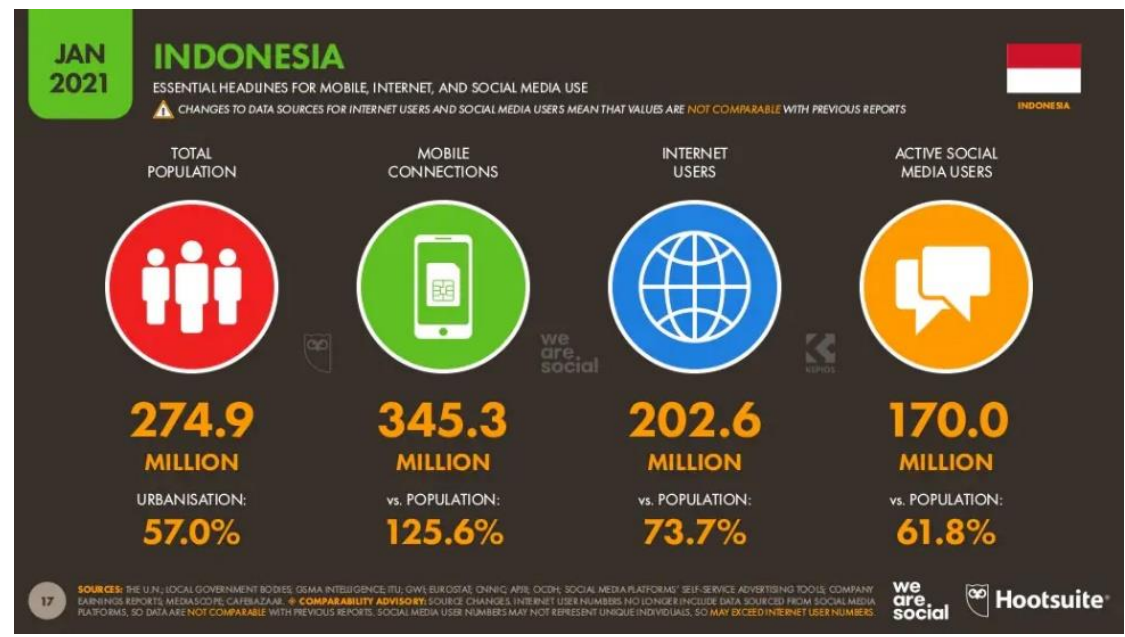

Gambar 1. Pengguna internet di Indonesia

Sumber : Datareportal.com 2021

Instagram merupakan aplikasi seluler pada sistem operasional iOS (Apple) dan Android (Google), dalam pengoperasiannya pengguna dapat mengambil serta merekayasa gambar atau video secara digital dan diposting di aplikasi Instagram serta media sosial lainnya. Gambar atau video yang diposting dapat dilihat di beranda akun orang lain yang menjadi follower (Winarso, 2015).

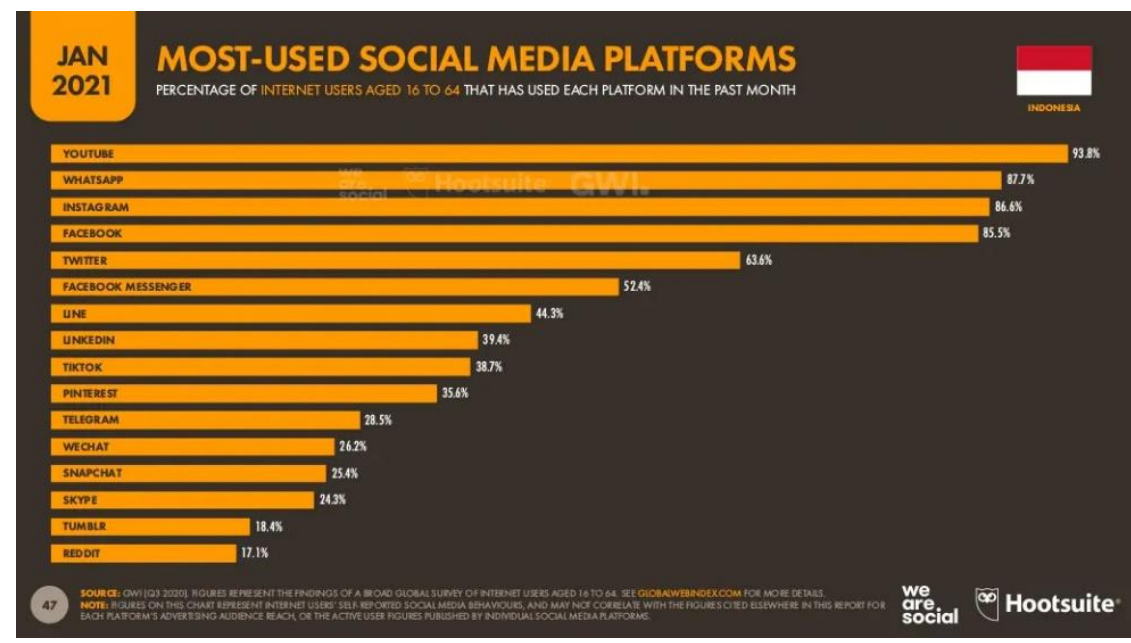

Gambar 2. Pengguna aplikasi internet di Indonesia Sumber : Datareportal.com 2021

Menjadi follower dalam akun Instagram, merupakan suatu keharusan bagi para pengguna untuk memenuhi kebutuhan informasi, sehingga informasi yang dicari akan lebih mudah didapat (Helen \& Rusdi, 2019). Sedangkan dari hasil penelitian yang dilakukan oleh Sri Wahyuni P, et al. (2019), ketertarikan pengguna Instagram untuk mengetahui informasi dari suatu akun Instagram pihak lain adalah konten yang unik dan menarik yang terdapat didalamnya. Ketika konten yang di unggah menarik, maka followers akan membuka konten Instagram tersebut untuk mengetahui informasi yang disampaikan. Dengan demikian informasi akan tersampaikan dan followers akan memberikan komentar terhadap konten tersebut. 
Konten yang unik dan menarik dalam Instagram sudah menjadi daya tarik tersendiri di antara para pengguna media sosial khususnya di kalangan remaja, hal ini karena Instagram tergolong aplikasi media sosial yang mempelopori dalam hal memposting dan berbagi foto serta video. Banyaknya jumlah pengguna Instagram kerap dimanfaatkan untuk menyampaikan berbagai informasi secara singkat. Dengan alasan inilah aplikasi Instagram bisa digunakan untuk menarik minat penggunanya untuk sesuatu hal, misalnya sebagai media pemasaran, media kampanye, penyelenggaran event dan informasi lainnya (Kurniawati \& Arifin, 2015).

Dengan mengakses informasi dari Instagram, baik melihat foto atau video terkait karya yang diunggah ke Instagram dapat membantu remaja mengembangkan kemampuan kreatifnya. Kreativitas sangat diperlukan, terutama dalam kegiatan pendidikan yang interaktif, agar remaja dapat menghasilkan sesuatu yang berbeda dari biasanya dalam proses belajar, dalam hal kemampuan mengekplorasi informasi yang diterima, baik dari guru maupun informasi yang diterima dari sekitarnya, sehingga remaja dapat memadukan informasi tersebut dalam proses belajarnya (Rubiyati et al., 2018).

Proses belajar mengajar di perguruan tinggi juga tidak lepas dari kemajuan teknologi, baik dari pengembangan kurikulum, sistem akademik hingga kegiatan mahasiswa. Salah satu pemanfaatan kemajuan teknologi adalah penyebaran informasi tentang dunia kampus. Dari sekian banyak perguruan tinggi, InterStudi merupakan salah satu institusi pendidikan yang memafaatkan teknologi informasi dalam hal ini internet dan media sosial. Informasi akan lebih cepat tersebar luas dengan memanfaatkan internet dan media sosial.

Kehadiran media sosial dipercaya memiliki peran besar dalam pembentukan dan meningkatkan Citra. Suatu lembaga atau orang pribadi dapat mencitrakan dirinya atau lembaganya melalui media sosial. Salah satu yang memerlukan citra adalah institusi pendidikan. Menurut penelitian Harahap, et al. (2020), citra yang positif akan membuat mahasiswa dan pihak lainnya menyukai suatu institusi pendidikan, sedangkan bagi intitusi pendidikan yang memiliki citra yang positif akan membantu aktivitas institusi tersebut dalam proses pemasaran hingga terlaksananya kegiatan belajar mengajar

Aplikasi Instagram adalah aplikasi media sosial yang mempermudah orang yang menggunakannya untuk saling bertukar informasi. Seperti media sosial lainnya, Instagram juga memfasilitasi transfer informasi ke berbagai belahan dunia dalam waktu singkat, yang berarti informasi dengan sangat mudah disebar ke berbagai akun Instagram. Sehingga melalui aplikasi Instagram kita bisa mendapatkan informasi dan menambah wawasan tentang berbagai hal (Maulhayat et al., 2018).

Akun Instagram yang dimiliki InterStudi adalah @interstudiofficial, yang dikelola oleh devisi media sosial. Instagram @interstudiofficial selalu mengunggah atau memposting konten secara rutin dan terjadwal. Beragam konten yang diposting berupa gambar dan tulisan serta video dengan tema yang beragam setiap harinya. Konten yang diposting biasanya tentang kegiatan mahasiswa, perkembangan teknologi, tips kecantikan, tips kesehatan, olah raga dan sebagainya.

Konten adalah istilah luas yang mengacu pada suatu hal/karya yang dibuat dan diupload ke situs web, baik berupa tulisan, gambar, vidio, atau benda lain yang ada di sana. Semua halaman web atau situs anda, juga adalah konten, halaman pertanyaan yang sering diajukan $(F A Q)$, produk halaman informasi, dan sebagainya. Semua hal yang Anda buat sebagai bagian dari halaman tersebut atau sebagai bagian dari imajinasi anda, video, blog, foto, webinar, buku putih, ebook, podcast, dan sebagainya juga merupakan konten (Handley \& Chapman, 2011).

Ketika akan membangun konten di Instagram ada hal-hal yang tidak boleh diabaikan: (1). Melakukan riset follower, (2). Membuat konten yang mempunyai tema, (3). Ada ciri 
khas tertentu pada desain, (4). Tentukan waktu posting yang tepat, (5). Ajak orang untuk berkomentar dipostingan (Adieb, 2019).

Selain untuk memposting konten berupa foto dan video, tujuan orang mempunyai akun Instagram antara lain untuk membaca komik, mencari lowongan pekerjaan, mencari irformasi beasiswa, mencari tempat liburan, update berita terbaru, mengetahui review makanan, berbelanja online dan mencari inspirasi baik di bidang seni ataupun arsitektur dan desain interior hingga melakukan promosi produk agar dikenal lebih luas (Hertian, 2016).

Dari penelitian Purbohastuti (2017), mahasiswa lebih tertarik untuk memanfaatkan media sosial untuk promosi, khususnya Instagram daripada melalui televisi dan media konvensional. Kemudahan akses menjadi alasan untuk publikasi di media social, karena dengan menggunakan handphone dapat mengupdate kapan dan di mana saja. Mendapatkan promosi gratis dengan jangkauna yang luas untuk pangsa pasar. Dengan demikian, memanfaatkan jejaring sosial untuk publikasi dan promosi begitu efektif bagi mahasiswa

Salah satu manfaat dari media sosial adalah untuk berekspresi (Sastiawan, 2021). Hasil dari ekspresi tersebut akan membentuk opini (Pakeh, 2020). Dari ungkapan Cutlip \& center, opini merupakan ungkapan mengenai sikap atas permasalahan tertentu yang sifatnya kontroversial (Broom \& Sha, 2013). Opini publik adalah hasil peleburan pemikiran dari hasil perbincangan didalam kelompok masyarakat yang demokratis (Bogardus, 2007). Opini publik tidak lain adalah dampak dari interaksi di antara pribadi-pribadi dalam komunitas apa saja (Albig, 2002).

Mahasiswa merupakan sekelompok orang yang sedang menuntut ilmu pada jenjang perguruan tinggi. Dengan tingkat pemikirannya mahasiswa terbiasa dengan mengemukakan pendapat, baik secara langsung di depan umum ataupun dengan menggunakan media informasi, baik itu media konvensional, internet dan media sosial (Kurniawan, 2021). Dari penelitian yang dilakukan Rama Arif Zulyadaini (2018), proses terwujudnya opini mahasiswa di institusi pendidikan swasta di Bandung, mengenai suatu informasi cukup tinggi. Tahap terbentuknya opini mahasiswa terhadap suatu informasi dapat dilihat dari aktivitas mahasiswa dalam mengutarakan komentarnya di kolom komentar di media sosial Instagram

Faktor yang membentuk opini publik: (1). Isu : harus ada kesepakatan jika opini publik terhimpun di sekitar isu. (2). Nature of Publics: Adanya komunitas yang sudah diketahui publik dan memiliki kepentingan dalam permasalahan isu tersebut. (3). Opsi yang rumit (complex of preferences), mengarah pada keseluruhan opini elemen kelompok mengenai suatu rumor. (4). Suatu ungkapan opini biasanya dapat menggunakan kata-kata secara verbal maupun non verbal. (5). Jumlah orang yang berpartisipasi : opini piblik merupakan besarnya kelompok/masyarakat yang memberikan perhatian tertang isu tersebut (Hennessy \& Sundquist, 2006).

Menurut R.P Abelson, untuk mengetahui opini seseorang bukanlah perkara sederhana, harus ada keterkaitan dengan: (1). Belief, keyakinan terhadap suatu hal (2). Attitude, suatu hal yang dirasakan atau menjadi sikapnya (3). Perception, tahap yang memberikan arti, bersumber dari bermacam faktor, antara lain: a). Budaya masyarakat, b). Kejadian yang diingat dari masa lampau seseorang/kelompok. c). Nilai-nilai yang diyakini (moral, etika, dan agama atau norma-norma yang ada pada masyarakat). d). Beredarnya kabar, anggapan, sehingga mempengaruhi pemikiran seseorang (Ruslan, 2010). Pendapat atau pandangan pribadi seseorang yang terjadi di media sosial akan berinteraksi diantara penggunanya, sehingga membangun opini yang sejenis, yang pada akhirnya bermuara pada opini publik. (Christiany Juditha, 2019).

Citra didefinisikan sebagai tanggapan pribadi seseorang mengenai sesuatu yang muncul dari pengalamannya dan pengetahuannya (Jefkins \& Jefkins, 2012). Beberapa 
macam citra, diantaranya : (1). The mirror image (cerminan citra) adalah gambaran citra organisasi yang diapresisai oleh masyarakat luar. (2). The current image (citra masih hangat) yaitu penilaian oleh kelompok orang dari luar tentang citra yang sedang terjadi pada organisasinya. (3). The wish image (citra yang harapkan) citra ini diterapkan pada suatu hal yang baru sebelum publik menerima keseluruhan informasi secara lengkap. (4). The multiple image (citra berlapis) yaitu beberapa citra dari pribadi masing-masing, anak perusahaan dan kantor cabang yang membangun citra tertentu dari instansi atau organisasi (Jefkins \& Jefkins, 2012).

Elemen citra antara adalah: (1). Personality, keseluruhan karakteristik perusahaan atau lembaga, (2). Reputasi, suatu hal yang dilakukan oleh institusi dan diakui oleh khalayak berdasarkan pengalaman mereka sendiri atau orang lain, (3). Value, atau nilai-nilai yang dipegang perusahaan atau kebiasaan yang dilakukan oleh perusahaan atau institusi yang telah menjadi identitas perusahaan seperti sikap kepedulian manajemen terhadap konsumen, 4) Corporate Identity, khususnya elemen yang memudahkan publik lbih mengenal perusahaan seperti logo, warna korporat dan moto perusahaan (Harrison, 1995).

Citra dalam pandangan institusi pendidikan adalah keseluruhan kesan atau pengalaman yang dirasakan oleh masyarakat, calon mahasiswa, mahasiswa dan institusi lain terhadap suatu perguruan tinggi. Mengenai fasilitas pendidikan, nama baik institusi, kualitas pendidikan seperti; akreditasi institusi pendidikan, fakultas dan program studi di kampus (Harahap, et al., 2020). Nama baik dan kualitas pendidikan akan mempengaruhi citra perguruan tinggi InterStudi yang dibangun atas kerja keras dari semua pihak dan unsur yang mendukungnya, dari dosen, karyawan dan stakeholder. Selain itu pula dari segi kurikulum, pelayanan kepada mahasiswa, pengabdian kepada masyarakat serta kemudahan dalam mengakses informasi tentang kampus akan menambah kepercayaan masyarakat terhadap perguruan tinggi InterStudi.

Keberadaan akun media sosial Instagram @interstudiofficial, diduga memiliki fungsi yang cukup penting dalam menyebarkan informasi seputar kampus InterStudi. Informasi atau konten yang disajikan akan memberikan dampak terhadap citra perguruan tinggi InterStudi. Dari pemaparan di atas dapat dirumuskan permasalahan penelitian, apakah ada pengaruh konten yang diunggah oleh akun Instagram @interstudiofficial serta opini mahasiswa InterStudi terhadap citra perguruan tinggi InterStudi. Tujuan dari penelitian ini adalah untuk mengetahui pengaruh konten Instagram @interstudiofficial dan opini mahasiswa terhadap citra perguruan tinggi InterStudi.

\section{METODOLOGI PENELITIAN}

Riset menggunakan pendekatan kuantitatif eksplanatif yang dilakukan pada suatu populasi dengan sampel tertentu. Pengumpulan data memanfaatkan kuesioner sebagai instrumen penelitian. Penelitian dilakukan di wilayah Jakarta dan sekitarnya yang merupakan wilayah domisili follower akun Instagram @interstudiofficial yang mayoritas mahasiswa dan alumni InterStudi. Populasi penelitian ini 2.650 orang yang merupakan follower@interstudiofficial. Teknik sampling yang digunakan adalah pengambilan sampel secara acak sederhana, dengan menggunakan rumus Taro Yamane diperoleh 97 responden. Kuesioner dirancang menggunakan skala Likert, sehingga variabel yang diukur akan diurai menjadi indikator variabel. Indikator-indikator tersebut kemudian menjadi acuan untuk menyusun komponen-komponen instrumen yang disajikan dalam bentuk pernyataan (Sugiyono, 2013). Penelitian ini menjelaskan keterkaitan antara tiga variabel dengan tujuan mengetahui sejauh apa variasi pada suatu faktor berkaitan dengan variasi pada faktor lainnya (Indra \& Cahyaningrum, 2019). Analisis regresi linier berganda digunakan untuk menguji 
pengaruh antara satu variable predictor (variable bebas) atas variabel terikat (Sugiyono, 2013).

\section{HASIL DAN PEMBAHASAN}

Setelah dilakukan pengolahan data dari hasil kuesioner terhadap responden didapat hasil sebagai berikut : Uji Validitas, dari hasil perhitungan dengan SPSS, $r$ hitung dari setiap item pernyataan berkisar 0,267 sampai 0,789, sedangkan $r$ tabel untuk 100 sampel adalah 0,195. Dengan nilai $\mathrm{r}$ hitung lebih besar dari $\mathrm{r}$ table, berarti angket dinyatakan valid. Uji Reliabilitas, dari hasil perhitungan analisis didapat nilai Alpha 0,975, sedangkan $\mathrm{r}$ table diketahui 0,195. Berarti nilai Alpha 0,975 > r table 0,195 dengan demikian angket dinyatakan reliable atau konsisten.

Tabel 1 : Hasil uji Reliabilitas

\begin{tabular}{|c|c|}
\hline \multicolumn{2}{|c|}{ Reliability Statistics } \\
\hline $\begin{array}{c}\text { Cronbach's } \\
\text { Alpha }\end{array}$ & $\mathrm{N}$ of Items \\
\hline .975 & 81 \\
\hline
\end{tabular}

Uji Normalitas: didapat nilai signifikansi 0,2 > 0,05, dengan demikian nilai residual berdistribusi normal.

Tabel 2 : Hasil uji Normalitas

\begin{tabular}{|c|c|c|}
\hline \multicolumn{3}{|c|}{ One-Sample Kolmogorov-Smirnov Test } \\
\hline \multicolumn{3}{|r|}{$\begin{array}{l}\text { Unstandardized } \\
\text { Residual }\end{array}$} \\
\hline $\mathrm{N}$ & & 100 \\
\hline \multirow[t]{2}{*}{ Normal Parameters ${ }^{\mathrm{a}, \mathrm{b}}$} & Mean & .0000000 \\
\hline & Std. Deviation & 6.47007004 \\
\hline \multirow[t]{3}{*}{ Most Extreme Differences } & Absolute & .069 \\
\hline & Positive & .069 \\
\hline & Negative & .059 \\
\hline Test Statistic & & .069 \\
\hline Asymp. Sig. (2-tailed) & & $200^{c, d}$ \\
\hline \multicolumn{3}{|c|}{ a. Test distribution is Normal. } \\
\hline \multicolumn{3}{|l|}{ b. Calculated from data. } \\
\hline \multicolumn{3}{|c|}{ c. Lilliefors Significance Correction. } \\
\hline \multicolumn{3}{|c|}{ d. This is a lower bound of the true significance. } \\
\hline
\end{tabular}

Uji Koefisien Korelasi: tujuan dilakukan uji korelasi adalah untuk mencari sejauh mana tingkat keeratan hubungan antar variabel yang dituangkan dalam koefisien korelasi.

Tabel 3 : Hasil uji Korelasi

\begin{tabular}{|c|c|c|c|c|}
\hline \multicolumn{5}{|c|}{ Correlations } \\
\hline & & Konten & Opini & Citra \\
\hline \multirow[t]{3}{*}{ Konten } & Pearson Correlation & 1 & $.826 "$ & $.789^{\prime \prime}$ \\
\hline & Sig. (2-tailed) & & .000 & .000 \\
\hline & $\mathrm{N}$ & 100 & 100 & 100 \\
\hline \multirow[t]{3}{*}{ Opini } & Pearson Correlation & $.826^{* \prime}$ & 1 & $.834^{* \prime}$ \\
\hline & Sig. (2-tailed) & .000 & & .000 \\
\hline & $\mathrm{N}$ & 100 & 100 & 100 \\
\hline \multirow[t]{3}{*}{ Citra } & Pearson Correlation & $.789^{*}$ & $.834^{*}$ & 1 \\
\hline & Sig. (2-tailed) & .000 & .000 & \\
\hline & $\mathrm{N}$ & 100 & 100 & 100 \\
\hline
\end{tabular}


Dari hasil perhitungan pada setiap variabel didapat nilai Signifikansi $0.00<0,05$, yang berarti setiap variabel berkorelasi mempunyai hubungan. Sedangkan untuk nilai korelasi (Pearson Correlation) dari tiap hubungan antar variable sebesar 0,789 hingga 0,834, dengan demikian dapat diartikan nilai korelari antar variabel berkorelasi kuat hingga sempurna.

Dari Tabel 3 dapat dilihat hubungan antara variabel konten dengan opini mahasiswa nilai korelasinya sebesar 0,826 berarti berkorelasi sempurna, sedangkan untuk hubungan variabel konten dengan citra sebesar 0,789 berarti berkorelasi kuat. Untuk hubungan antar variable opini mahasiswa dengan variabel konten nilai korelasinya sebesar 0,826 berarti berkorelasi sempurna, sedangkan untuk hubungan variabel opini mahasiswa dengan citra nilai korelasinya sebesar 0,834 berarti berkorelasi sempurna. Untuk hubungan antar variabel citra dengan konten nilai korelasinya sebesar 0,789 berarti berkorelasi kuat, sedangkan untuk hubungan antara variabel citra dengan opini mahasiswa nilai korelasinya sebesar 0,834 yang berarti berkorelasi sempurna.

Uji Regresi Linier Berganda (Uji t) : tujuan dari dilakukannya analisis regresi berganda untuk mengetahui ada atau tidaknya pengaruh dua bahkan lebih variabel bebas (X) terhadap variabel terikat (Y). Adapun tujuan dari Uji t adalah untuk mengetahui ada atau tidaknya pengaruh parsial (sendiri) yang dihasilkan dari variabel bebas (X) terhadap variabel terikat (Y) (Sugiyono, 2013).

Tabel 4 : Hasil Uji Regresi Linaer Berganda (Uji t)

\begin{tabular}{|c|c|c|c|c|c|c|}
\hline \multicolumn{7}{|c|}{ Coefficients $^{a}$} \\
\hline & & \multicolumn{2}{|c|}{ Unstandardized Coefficients } & \multirow{2}{*}{$\begin{array}{c}\text { Standardized } \\
\text { Coefficients } \\
\text { Beta }\end{array}$} & \multirow[b]{2}{*}{$\mathrm{t}$} & \multirow[b]{2}{*}{ Sig. } \\
\hline \multicolumn{2}{|c|}{ Model } & B & Std. Error & & & \\
\hline \multirow[t]{3}{*}{1} & (Constant) & 1.234 & 3.359 & & .368 & .714 \\
\hline & Konten & .351 & .105 & .316 & 3.355 & .001 \\
\hline & Opini & .677 & .111 & .573 & 6.079 & .000 \\
\hline
\end{tabular}

Uji hipotesis pertama (H1)

Didapat nilai Sig. untuk pengaruh X1 (konten) terhadap Y (citra) adalah sebesar $0,001<0,05$ dan t hitung 3,355 > t table 1,98397, dengan demikian H1 diterima yang artinya ada pengaruh $\mathrm{X} 1$ terhadap $\mathrm{Y}$

Uji hipotesis kedua $(\mathrm{H} 2)$

Didapat nilai Sig. untuk pengaruh X2 (opini mahasiswa) terhadap Y (citra) sebesar $0,000<0,05$ dan thitung 6,079>t table 1,98397, dengan hasil tersebut $\mathrm{H} 2$ diterima yang artinya ada pengaruh X2 terhadap Y. Uji Regresi Linier Berganda (Uji F) : menguji pengaruh satu variable bebas terhadap variable terikat.

Tabel 5 : Hasil Uji Regresi Linaer Berganda (Uji F)

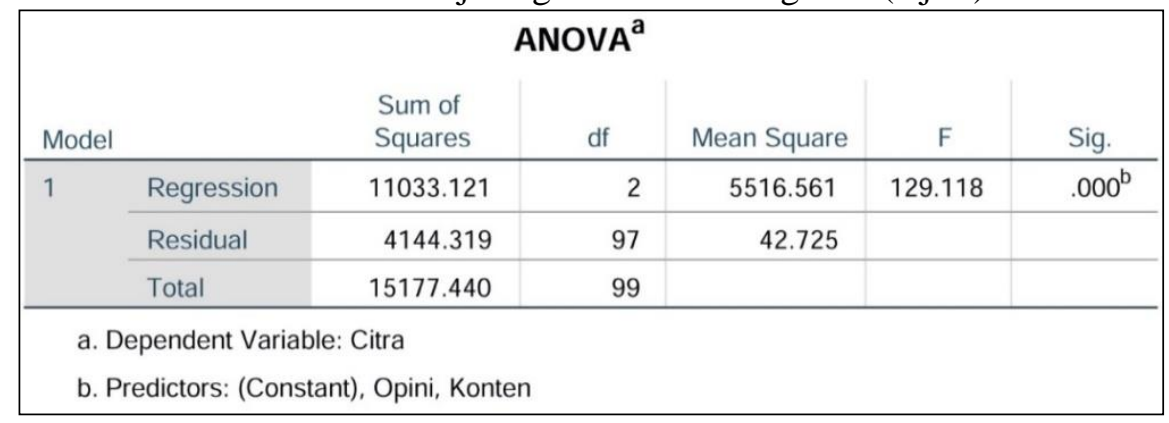




\section{Uji Hipotesis Ketiga (H3)}

Dari hasil perhitungan pada Tabel 5, didapat nilai signifikansi untuk pengaruh $\mathrm{X} 1$ (konten) dan X2 (opini mahasiswa) secara simultan terhadap Y (citra) bernilai 0,000<0,05 dan nilai $\mathrm{F}$ hitung 129,118 > F table 3,09, dengan demikian $\mathrm{H} 3$ diterima yang artinya ada pengaruh X1 dan X2 secara simultan terhadap Y.

Uji Koefisien Determinasi

Tabel 6 : Hasil uji Koefisien Determinasi Konten terhadap Citra

\begin{tabular}{|c|c|c|c|c|}
\hline \multicolumn{5}{|c|}{ Model Summary } \\
\hline Model & $\mathrm{R}$ & R Square & $\begin{array}{l}\text { Adjusted R } \\
\text { Square }\end{array}$ & $\begin{array}{l}\text { Std. Error of the } \\
\text { Estimate }\end{array}$ \\
\hline 1 & $.789^{a}$ & .623 & .619 & 7.642 \\
\hline
\end{tabular}

Analisis output 1; Variabel Konten terhadap Citra, diketahui R Square bernilai 0,623 sehingga dapat diartikan bahwa besaran pengaruh variable Konten Instagram terhadap Citra sebesar $62,3 \%$.

Tabel 7 : Hasil uji Koefisien Determinasi Opini terhadap Citra

\begin{tabular}{|l|l|c|c|c|}
\hline \multicolumn{7}{|c|}{ Model Summary } \\
Model & $\mathrm{R}$ & R Square & $\begin{array}{c}\text { Adjusted R } \\
\text { Square }\end{array}$ & $\begin{array}{c}\text { Std. Error of the } \\
\text { Estimate }\end{array}$ \\
\hline 1 & $.834^{\text {a }}$ & .695 & .692 & 6.870 \\
\hline \multicolumn{2}{|c|}{ a. Predictors: (Constant), Opini } & \\
\hline
\end{tabular}

Analisis output 2; Opini terhadap Citra, diketahui nilai R Square sebesar 0,695 maka dapat diartikan bahwa besaran pengaruh variable Opini Mahaisswa terhadap Citra sebesar $69,5 \%$.

\section{Pembahasan}

Dari hasil penelitian dan uraian di atas dapat diartikan bahwa tampilan atau desain konten Instagram sangat mempengaruhi ketertarikan mahasiswa yang menjadi followers untuk membaca informasi dengan lengkap. Konten dan informasi yang disampaikan akan dinilai oleh followers baik dari segi desain maupun dari isi informasinya. Ketika informasi yang disampaikan oleh admin Instagram @interstudiofficial dibuat dengan konten yang menarik, maka followers akan memberi tanggapan dengan menulis komentar.

Temuan ini menegaskan bahwa Instagram dianggap sebagai sarana yang sangat efektif untuk peningkatan citra dan awareness serta menambah pengetahuan. Banyak akun Instagram dimanfaatkan untuk kampanye atau hanya menyebarluaskan informasi tertentu. Fitur-fitur yang dimiliki Instagram dapat membantu dan memudahkan penggunanya untuk menyebarkan informasi dengan jangkauan sangat luas (Ramdan et al., 2019).

Mahasiswa mencurahkan ekpresi atas informasi yang diterima dari akun Instagram @InterStudi official dengan menuliskan komentar pada kolom komentar di akun Instagram tersebut. Komentar-komentar tersebut akan berkembang menjadi opini mahasiswa atas apa yang dia ketahui tentang isi konten atau informasi tersebut. Baik atau buruknya penilaian 
mahasiswa melalui komentar akan mempengaruhi citra InterStudi, karena orang lain akan membaca informasi yang ada pada akun Instagram tersebut.

Untuk menilai sesuatu informasi, mahasiswa akan dipengaruhi oleh cognition (pengertian atau nalar), penalaran mahasiswa terhadap bekenaran pada suatu informasi yang diterima, berhubungan dengan pendiriannya. Faktor cognition akan mengarah pada penilaian atau pemahaman siswa berdasarkan rasio atau kemampuan nalarnya. Dengan demikian kognitif merupakan bagian dari kemampuan intelektual manusia yang berkaitan dengan ilmu pengetahuan (Rama Arif Zulyadaini, 2018).

Keberadaan akun media sosial seperti akun Instagram@interstudiofficial membantu meningkatkan citra perguruan tinggi InterStudi. Hal ini karena ketika akun Instagram @ interstudiofficial mengunggah informasi yang positif tentang InterStudi, maka feedback atau respons yang didapat juga akan positif. Hal ini dapat meningkatkan citra InterStudi di mata masyarakat khususnya di kalangan mahasiswa yang mempunyai akun Instagram.

Menurut penelitian yang di lakukan oleh Sanjaya Sip \& Ramadhani (2014) dengan adanya akun media social Instagram dan Twitter, para follower yang merupakan pelanggan, akan dimudahkan untuk mendapat informasi terbaru tentang produk, sehingga pelanggan akan terpikat untuk membeli produk yang efeknya dapat membangun loyalitas konsumen.

Jika dilihat dari jumlah jawaban terbanyak atas pernyataan dari tiap idikator, yang artinya indikator tersebut lebih banyak direspon secara positif. Maka dapat diuraikan sebagai berikut :

Tabel 8. Hasil survei pada variabel konten Instagram

\begin{tabular}{|c|c|c|c|c|}
\hline No & $\begin{array}{l}\text { Variabel } \\
\text { Konsep }\end{array}$ & $\begin{array}{l}\text { Dimensi } \\
\text { Kategori }\end{array}$ & Indikator & $\begin{array}{c}\text { Jumlah responden yang } \\
\text { memilih (tertinggi \& } \\
\text { terendah) }\end{array}$ \\
\hline \multirow{6}{*}{1} & \multirow{6}{*}{$\begin{array}{l}\text { Konten } \\
\text { Instagram }\end{array}$} & \multirow{2}{*}{$\begin{array}{l}\text { Informasi } \\
\text { yang } \\
\text { disampaikan } \\
\text { / diunggah }\end{array}$} & $\begin{array}{l}\text { Menyajikan informasi-informasi } \\
\text { yang menarik, untuk kalangan } \\
\text { remaja/mahasiswa. }\end{array}$ & 73 responden "Setuju" \\
\hline & & & $\begin{array}{l}\text { Informasi yang disampaikan } \\
\text { sesuai dengan kebutuhan } \\
\text { kehidupan remaja/mahasiswa. }\end{array}$ & $\begin{array}{l}1 \text { responden } \\
\text { "Sangat tidak setuju" }\end{array}$ \\
\hline & & \multirow[b]{2}{*}{$\begin{array}{l}\text { Tema/materi } \\
\text { konten }\end{array}$} & $\begin{array}{l}\text { Tema konten bervariatif dan } \\
\text { selalu berbeda di setiap } \\
\text { unggahan }\end{array}$ & 64 responden "Setuju" \\
\hline & & & $\begin{array}{l}\text { Materi/tema yang disajikan bisa } \\
\text { menjadi contoh untuk para } \\
\text { mahasiswa (seperti tips } \\
\text { kesehatan, olah raga, } \\
\text { kecantikan). }\end{array}$ & $\begin{array}{c}1 \text { responden } \\
\text { "Sangat tidak setuju" }\end{array}$ \\
\hline & & \multirow{2}{*}{$\begin{array}{l}\text { Tampilan } \\
\text { desain } \\
\text { konten }\end{array}$} & $\begin{array}{l}\text { Informasi yang di tampilkan di } \\
\text { sertai foto, gambar ilustrasi } \\
\text { ataupun video. }\end{array}$ & 69 responden "Setuju" \\
\hline & & & $\begin{array}{l}\text { Menyertakan kalimat yang } \\
\text { membuat mahasiswa tertarik } \\
\text { akan informasi yang di sajikan. }\end{array}$ & $\begin{array}{l}1 \text { responden } \\
\text { "Sangat tidak setuju" }\end{array}$ \\
\hline
\end{tabular}

Sumber : Hasil penelitian 
Dari uraian di atas dapat dijelaskan bahwa pada variabel konten, mahasiswa lebih cenderung menyukai konten yang menarik dan bervariatif yang disertai gambar ilustrasi atau foto. Konten yang menarik pada Instagram @interstudiofficial akan memberikan dampak positif terhadap citra perguruan tinggi InterStudi. Penelitian sebelumnya juga menjelaskan, followers Instagram lebih menyukai konten dengan gambar/ foto yang menarik. Dengan menampilkan hasil foto yang berkualitas akan mendorong followers untuk berkomentar atau memberikan tanda hati, bahkan membeli makanan atau minuman yang ada dalam konten tersebut (Sri Wahyuni P, Finnah Fourqoniah, 2019).

Tabel 9. Hasil survei pada variabel opini mahasiswa

\begin{tabular}{|c|c|c|c|c|}
\hline No & $\begin{array}{l}\text { Variabel } \\
\text { Konsep }\end{array}$ & $\begin{array}{l}\text { Dimensi } \\
\text { Kategori }\end{array}$ & Indikator & $\begin{array}{c}\text { Jumlah responden } \\
\text { yang memilih } \\
\text { (tertinggi \& terendah) }\end{array}$ \\
\hline \multirow{7}{*}{2} & \multirow{7}{*}{$\begin{array}{l}\text { Opini } \\
\text { Mahasiswa }\end{array}$} & \multirow{3}{*}{$\begin{array}{l}\text { Belief / } \\
\text { keyakinan }\end{array}$} & $\begin{array}{l}\text { Mahasiswa percaya tentang } \\
\text { reputasi InterStudi. }\end{array}$ & 72 responden "Setuju" \\
\hline & & & \multirow{2}{*}{$\begin{array}{l}\text { Mahasiswa percaya akan } \\
\text { kualitas para dosen InterStudi. }\end{array}$} & 1 responden \\
\hline & & & & "Sangat tidak setuju" \\
\hline & & \multirow[t]{2}{*}{ Attitude / sikap } & $\begin{array}{l}\text { Mahasiswa bersikap ingin tahu } \\
\text { terhadap informasi yang } \\
\text { disampaikan dalam akun } \\
\text { @interstudiofficial. }\end{array}$ & 65 responden "Setuju" \\
\hline & & & $\begin{array}{l}\text { Mahasiswa bersikap ingin tahu } \\
\text { terhadap kualitas dosen } \\
\text { pengajar InterStudi. }\end{array}$ & $\begin{array}{l}1 \text { responden } \\
\text { "Tidak setuju" }\end{array}$ \\
\hline & & \multirow[t]{2}{*}{ Persepsi } & $\begin{array}{l}\text { Informasi yang di sajikan akun } \\
\text { @InterStudi official sangat } \\
\text { jelas. }\end{array}$ & 73 responden "Setuju" \\
\hline & & & $\begin{array}{l}\text { Konten dalam akun } \\
\text { @ interstudiofficial sangat } \\
\text { menarik. }\end{array}$ & $\begin{array}{l}1 \text { responden } \\
\text { "Sangat tidak setuju" }\end{array}$ \\
\hline
\end{tabular}

\section{Sumber : Hasil penelitian}

Dari hasil survey pada variabel opini mahasiswa, dapat dijelaskan jika mahasiswa masih mempercayai perguruan tinggi InterStudi masih memiliki reputasi baik dan mahasiswa memiliki rasa ingin tahu tentang informasi yang disampaikan oleh akun Instagram @interstudiofficial. Menurut Ruslan (2010), salah satu faktor pembentuk opini adalah kognisi atau nalar, kognisi ini berhubungan dengan pemahaman pribadi untuk menilai sesuatu informasi, yang berhubungan dengan pendapatnya. Dengan faktor kognisi, seseorang akan memberikan penilaian berdasarkan rasio atau kemampuan penalarannya (Ruslan, 2010). 
Tabel 10. Hasil survei pada variabel citra perguruan tinggi

\begin{tabular}{|c|c|c|c|c|}
\hline No & $\begin{array}{l}\text { Variabel } \\
\text { Konsep }\end{array}$ & $\begin{array}{l}\text { Dimensi } \\
\text { Kategori }\end{array}$ & Indikator & $\begin{array}{c}\text { Jumlah responden } \\
\text { yang memilih } \\
\text { (tertinggi \& terendah) }\end{array}$ \\
\hline \multirow{6}{*}{1} & \multirow{6}{*}{$\begin{array}{l}\text { Citra } \\
\text { Perguruan } \\
\text { Tinggi }\end{array}$} & \multirow[t]{2}{*}{$\begin{array}{l}\text { Value / nilai- } \\
\text { nilai }\end{array}$} & $\begin{array}{l}\text { Suasana kampus sangat asri } \\
\text { sehingga mahasiswa betah } \\
\text { ketika berada di kampus } \\
\text { InterStudi. }\end{array}$ & 60 responden "Setuju" \\
\hline & & & $\begin{array}{l}\text { Fasilitas kampus memadai } \\
\text { untuk kegiatan belajar } \\
\text { mengajar. }\end{array}$ & $\begin{array}{c}1 \text { responden } \\
\text { "Sangat tidak setuju" }\end{array}$ \\
\hline & & \multirow[t]{2}{*}{ Reputasi } & $\begin{array}{lr}\text { Berperan } & \text { dalam } \\
\text { meningkatkan } & \text { mutu } \\
\text { pendidikan. } & \end{array}$ & 70 responden "Setuju" \\
\hline & & & $\begin{array}{l}\text { Ikut serta dalam pengabdian } \\
\text { masyarakat. }\end{array}$ & $\begin{array}{l}2 \text { responden } \\
\text { "Sangat tidak setuju" }\end{array}$ \\
\hline & & \multirow{2}{*}{ Personality } & $\begin{array}{l}\text { Akun sosial media InterStudi } \\
\text { mudah di akses. }\end{array}$ & 64 responden "Setuju" \\
\hline & & & $\begin{array}{l}\text { Iklan yang di sajikan } \\
\text { menarik. }\end{array}$ & $\begin{array}{l}2 \text { responden } \\
\text { "Sangat tidak setuju" }\end{array}$ \\
\hline
\end{tabular}

Sumber : Hasil penelitian

Dari data di atas dapat diketahui mahasiswa menilai citra perguruan tinggi InterStudi dari apa yang mereka rasakan dan mereka dapatkan dari kampus selama kuliah di InterStudi. Makin nyaman mereka kuliah dan makin bertambah ilmu yang mereka dapatkan, maka mereka akan menilai citra InterStudi akan semakin baik. Penelitian sebelumnya juga menjelaskan, citra yang terbentuk dapat mewujudkan sesuatu yang kualitas tinggi yang diharapkan dan diterima oleh mahasiswa. Hal ini harus dibuktikan secara nyata, bukan hanya sekedar laporan yang disampaikan institusi tanpa ada bukti (Harahap, Amanah, Gunarto, Umam, et al., 2020).

\section{PENUTUP}

Penelitian ini menyimpulkan bahwa: (1). Mahasiswa akan merespons konten yang diunggah dalam akun Instagram @interstudiofficial apabila informasi yang disampaikan dibuat menarik; (2). Ketika mahasiswa menuliskan komentar di akun Instagram @interstudiofficial akan berkembang menjadi opini mahasiswa dan akan memberikan dampak kepada citra perguruan tinggi InterStudi; (3). Keberadaan akun media sosial seperti akuninstagram @interstudiofficial, sangat membantu untuk meningkatkan citra perguruan tinggi InterStudi; (4). Konten Instagram @interstudiofficial akan mempengaruhi citra perguruan tinggi InterStudi sebesar 62,3\% dan 37,7 \% akan dipengaruhi dari faktor lainnya. Sedangkan opini mahasiswa akan mempengaruhi citra perguruan tinggi InterStudi sebesar $69,5 \%$ dan 30,5\% akan dipengaruhi dari faktor lainnya.

Berdasarkan temuan penelitian tersebut, penulis memberi saran sebagai berikut: (1). Mengacu pada kesimpulan, ada faktor lain yang mempengaruhi citra perguruan tinggi InterStudi selain dari konten Instagram dan opini mahasiswa, hal ini perlu penelitian lebih lanjut; (2). Penilaian followers terhadap konten sudah dinilai baik, namun belum diketahui 
apakah konten atau informasi yang diunggah oleh admin akun Instagram @interstudiofficial di-repost atau diteruskan oleh para followers sehingga informasi tersebut lebih tersebar luas, hal ini masih perlu penelitian lebih lanjut; (3). Admin akun Instagram @interstudiofficial harus menjaga dan meningkatkan kualitas konten yang diunggah untuk tetap menjaga citra perguruan tinggi InterStudi.

\section{REFERENSI}

Adieb. (2019). 5 Tips Membangun Konten Instagram Untuk Bisnis - Bizlab - Collaborative Learning. Bizlab.Co.Id. https://bizlab.co.id/5-tips-membangun-konten-instagramuntuk-bisnis/

Albig, W. (2002). Two Decades of Opinion Study: 1936-1956. Public Opinion Quarterly. https://doi.org/10.1086/266681

Ardiyanto, E. (2013). Handbook of Public Relations. Simbiosa Rekatama Media, Bandung.

Bogardus, E. S. (2007). Fundamentals of Social Psychology. The American Catholic Sociological Review. https://doi.org/10.2307/3707450

Broom, G. M., \& Sha, B.-L. (2013). Cutlip and Center's effective public relations. 431. http://libgen.is/book/index.php?md5=1FE1E3555A72A089ACA57796247AB54D

Christiany Juditha. (2019). Opini Publik Terhadap Kasus "KPK Lawan Polisi" dalam Media Sosial Twitter. https://doi.org/http://dx.doi.org/10.33164/iptekkom.20.2.2018.137-152

Datareportal.com. (2021). Digital in Indonesia: All the Statistics You Need in 2021 DataReportal - Global Digital Insights.

https://datareportal.com/reports/digital-2021-indonesia

Handley, A., \& Chapman, C. C. (2011). Content rules : how to create killer blogs, podcasts, videos, ebooks, webinars (and more) that engage customers and ignite your business. 282. http://libgen.is/book/index.php?md5=4B50654069E7CC2AF861626E8034D126

Harahap, D. A., Amanah, D., Gunarto, M., Umam, K., Ekonomi, F., Universitas, B., \& Bandung, I. (2020). PENTINGNYA CITRA UNIVERSITAS DALAM MEMILIH STUDI DI PERGURUAN TINGGI. Niagawan, 9(3), 191-196.

https://doi.org/10.24114/NIAGA.V9I3.20819

Harrison, S. (1995). Public relations an introduction. Null.

Helen, H., \& Rusdi, F. (2019). Pengaruh Penggunaan Media Sosial Akun Instagram @ Jktinfo Terhadap Pemenuhan Kebutuhan Informasi Followers. Prologia, 2(2), 355. https://doi.org/10.24912/pr.v2i2.3712

Hennessy, B., \& Sundquist, J. L. (2006). Dynamics of the Party System: Alignment and Realignment of Political Parties in the United States. The Western Political Quarterly, 27(2), 345. https://doi.org/10.2307/447776

Hertian, N. (2016). 11 Kegunaan Instagram yang Nggak Kamu Tau Padahal Penting Banget. $\quad$ https://www.shopback.co.id/katashopback/11-kegunaan-instagram-yangnggak-kamu-tau-padahal-penting-banget

Indra, I. M., \& Cahyaningrum, I. (2019). Cara Mudah Memahami Metodologi Penelitian - 
Google Books.

https://www.google.co.id/books/edition/Cara_Mudah_Memahami_Metodologi_Penelitia/e-iDwAAQBAJ?hl=id\&gbpv=0

Jefkins, F., \& Jefkins, F. (2012). International Dictionary of Marketing and Communication. In International Dictionary of Marketing and Communication. https://doi.org/10.1007/978-1-4684-1523-0_1

Kurniawan, A. (2021). Pengertian Mahasiswa, Peran, Fungsi, Ciri \& Menurut Para Ahli. Gurupendidikan.Co.Id. https://www.gurupendidikan.co.id/pengertian-mahasiswa/

Kurniawati, D., \& Arifin, N. (2015). Strategi Pemasaran Melalui Media Sosial dan Minat Beli Mahasiswa. JURNAL SIMBOLIKA: Research and Learning in Communication Study, 1(2). https://doi.org/10.31289/SIMBOLLIKA.V1I2.200

Maulhayat, F., Kesuma, A. I., \& Amiruddin, H. (2018). Peran Instagram Di Kalangan Mahasiswa Angkatan 2015 Fakultas Ilmu Sosial Universitas Negeri Makassar. http://eprints.unm.ac.id/9871/

Pakeh, A. (2020). Menulis Opini, Ekspresi Diri Lewat Tulisan. Sosiologi.Utu.Ac.Id. http://sosiologi.utu.ac.id/posts/read/menulis-opini-ekspresi-diri-lewat-tulisan

Purbohastuti, A. W. (2017). EFEKTIVITAS MEDIA SOSIAL SEBAGAI MEDIA PROMOSI. Tirtayasa Ekonomika, 12(2), 212. https://doi.org/10.35448/jte.v12i2.4456

Rama Arif Zulyadaini, N. Y. (2018). Opini Mahasiswa tentang Berita Hoax (Studi Deskriptif mengenai Opini Mahasiswa Fakultas Ilmu Komunikasi Universitas Islam Bandung tentang Berita Hoax di Instagram) | Zulyadaini | Prosiding Hubungan Masyarakat. http://karyailmiah.unisba.ac.id/index.php/humas/article/view/12703

Ramdan, A. K., Rismawan, F. R., Wiharnis, N., \& Safitri, D. (2019). Pengaruh Akun Instagram @temandisabilitas_Id dalam Meningkatkan Kesadaran Followers Terhadap Difabel. Inter Komunika: Jurnal Komunikasi, 4(2), 104-115.

https://doi.org/10.33376/IK.V4I2.284

Rubiyati, R., Asrori, M., \& Wicaksono, L. (2018). PENGARUH PEMANFAATAN MEDIA SOSIAL INSTAGRAM TERHADAP KREATIVITAS BELAJAR PADA REMAJA KELAS VII. Jurnal Pendidikan Dan Pembelajaran Khatulistiwa, 7(5).

https://jurnal.untan.ac.id/index.php/jpdpb/article/view/25681

Ruslan, R. (2010). Manajemen Public Relations dan Media Komunikasi. Rajawali Pers.

Sanjaya Sip, M., \& Ramadhani, G. (2014). PENGARUH SOCIAL MEDIA TWITTER SEBAGAI ALAT PROMOSI TERHADAP LOYALITAS PELANGGAN (STUDI KASUS FRED PERRY PLAZA INDONESIA PERIODE FEBRUARI-APRIL 2013)

Oleh. In LONTAR: Jurnal Ilmu Komunikasi (Vol. 2, Issue 3).

https://doi.org/10.30656/LONTAR.V2I3.340

Sastiawan, D. (2021). 5 Manfaat Utama Media Sosial untuk Pelajar dan Mahasiswa Website Resmi Dinas KOMINFOSAN Kota Bengkulu. Kominfo.Bengkulukota.Go.Id.

https://kominfo.bengkulukota.go.id/5-manfaat-utama-media-sosial-untuk-pelajar-danmahasiswa/

Sri Wahyuni P, Finnah Fourqoniah, A. W. A. (2019). Dunia Komunikasi | PENGARUH 
KONTEN INSTAGRAM @SMRFOODIES TERHADAP MINAT BELI FOLLOWERS (Sri Wahyuni P., Finnah Fourqoniah, Annisa Wahyuni Arsyad).

https://ejournal.ilkom.fisip-unmul.ac.id/site/?p=3785

Sugiyono. (2013). Metode Penelitian Pendidikan Pendekatan Kuantitaif, Kualitatif, dan R\&D. In Metode Penelitian Pendidikan Pendekatan Kuantitaif, Kualitatif, dan R\&D. https://doi.org/10.1007/s13398-014-0173-7.2

Winarso, B. (2015). Apa Itu Instagram, Fitur dan Cara Menggunakannya? | Dailysocial. https://dailysocial.id/post/apa-itu-instagram

Yunani, W. (2016). Dikti | Sinergi Dosen-Mahasiswa untuk Tingkatkan Kualitas Dikti. Duniadosen.Com. https://www.duniadosen.com/tingkatkan-kualitas-dikti/

Zarrella, D. (2012). Das Social Media-Marketing Buch. In O’Reilly. 